\title{
JUURNAL_RU
}

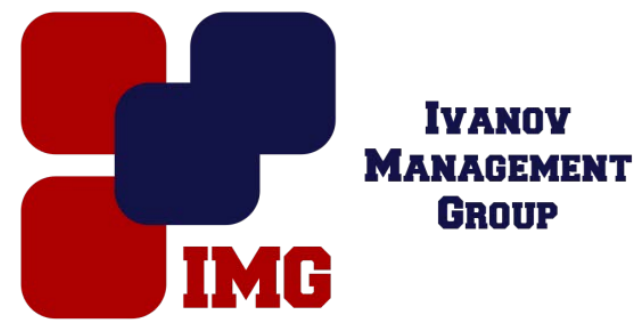

Таилова А.Г., Мусаева Р.М. Дагестанский государственный университет Избербаш, Россия

doi: 10.18411/lj-31-10-2016-3-11

idsp 000001:lj-31-10-2016-3-11

\section{Неблагоприятное окружение по месту работы как фактор корыстных посягательств на предприятии}

В статье анализируется особенности причин и условий способствующих совершению хищений на предприятии. Условия и окружение по месту работы, организационная структура, технологические решения производственных процессов и т. д. могут благоприятствовать совершению преступлений.

Ключевые слова: хищение чужого имущества, бесхозяйственность, преступление, неблагоприятное окружение.

В процессе труда осуществляется воспитание и обучение и обеспечивается функционирование экономики: производство, распределение, обмен и потребление материальных благ и услуг. Однако в то же время условия и окружение по месту работы, организационная структура, технологические решения производственных процессов и т. д. могут благоприятствовать совершению преступлений. Анализ уголовных дел подтверждает, что в генезисе многих хозяйственных преступлений эти факторы сыграли определенную роль.

Массовые кражи на производстве возможны потому, что расхитители не осуждаются другими работниками, что здесь нет групп, которые связывают свое благополучие с интересами работодателей, наоборот- общественное мнение, господствующее па таких предприятиях, формируют анархистски настроенные группы, распространяющие унылый лозунг «не украдешь - не проживешь», 
принимаемый несмотря на тот очевидный факт, что крадут также и те, кто зарабатывает очень хорошо.

Изучение социально-психологической обусловленности корыстной преступности приводит к выводу, что наиболее восприимчивы к подстрекательству на совершение корыстных преступлений те работники, которые получают относительно низкую зарплату и имеют скромный доход. Эти же исследования показывают, что инициатива в развязывания преступной деятельности принадлежит лицам, материальное положение которых следует признать благополучным. Противоправное поведение этой категории людей обусловлено не обстоятельствами экономического характера и не расстройствами личности. Указанное поведение следует рассматривать как результат усвоения неправильных моральных ценностных систем.

Общей чертой, характеризующей атмосферу предприятий, на которых совершаются экономические преступления, является низкий уровень «обобществления» нормы «не укради», отсутствие полного и правильного понимания смысла чужой собственности. Это требует применения соответствующих мер коррекции, сложных средств воздействия - и не только репрессивных.

К числу факторов, играющих определенную роль в экономической преступности, нужно отнести такие организационные решения в экономике, в результате которых работники попадают под действие противоположных стимулов и противоречащих друг другу предписаний. Частое возникновение конфликтных ситуаций может быть не только причиной неврозов, но и обстоятельством, усыпляющим внимание контролирующих органов и т. п. В таких случаях реакция может иметь сугубо индивидуальный характер в зависимости от сопротивляемости эмоциональным напряжениям.

Наиболее распространенными формами преступности, связанной с производственной деятельностью, являются нарушение правил техники безопасности, бесхозяйственность, а также разного рода присвоение общественного имущества.

На стыке производственной деятельности и управления экономикой возможны такие преступления, как взяточничество и подделка документов. 
Нарушения правил техники безопасности наиболее часто связаны с халатностью и легкомыслием работников, а также технического контроля при соблюдении технологического режима, использовании специальной рабочей одежды и приспособлений для индивидуальной защиты. Такое отношение (к мерам дисциплинарного и иного воздействия на обнаруженные правонарушения в этой сфере) порой отождествляется с доброжелательством, и только несчастный случай на производстве, угроза жизни либо здоровью позволяют заметить его общественную опасность.

К указанной группе деяний, главным образом по своим последствиям, близко небрежное и недобросовестное выполнение работ по ремонту и консервации. Обеспечение бесперебойной эксплуатации машин и механизмов, особенно в условиях перегрузки производственных мощностей, ставит перед ремонтно-консервационными службами ответственные задачи. Любая неточность может в короткий срок привести к аварии, угрожающей гибелью людей, и большому материальному ущербу.

Все эти соображения приводят к выводу, что между бесхозяйственностью и ее последствиями существует своего рода обратная связь, а именно: присвоение чужого имущества (даже мелкое), совершаемое в течение длительного времени, является симптомом бесхозяйственности. Недостатки хозяйственного учета затрудняют выполнение связанных с ним функций. Указанные недостатки затрудняют надлежащий анализ хозяйственных процессов и выявление фактов бесхозяйственности, присвоения и иного вреда имуществу. Среди преступлений, связанных с производственной деятельностью, самую большую группу составляет присвоение чужого имущества.

Особую опасность представляют организованные преступные группы, складывающиеся в разных отраслях производства. В эти группы вербуется часто принудительно, лица, выполняющие на предприятии определенные функции[1,с.145]. Имеются в виду, например, работники учетных либо контрольных подразделений. На предприятиях, где существуют такие неформальные группы, создается атмосфера негативного отношения к любым ценностям, в том числе к честному труду на производстве и в сфере обслуживания. 


\section{Литература}

1. Таилова А.Г. Проблемы квалификации преступлений. Краткий курс лекций. Махачкала 2015. 